\title{
KONCEPCJA SMART CITY JAKO PRZEDMIOT ZAINTERESOWANIA BIBLIOLOGII I INFORMATOLOGII
}

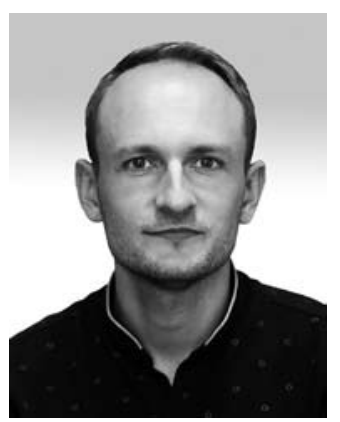

Przemysław Krysiński, mgr, asystent w Instytucie Informacji Naukowej i Bibliologii Uniwersytetu Mikołaja Kopernika w Toruniu. Interesuje się cyfrowymi usługami publicznymi, nowymi technologiami, projektowaniem i wdrażaniem systemów CMS, wyszukiwaniem informacji oraz e-learningiem. Współtwórca kursów e-learningowych: „Bibweb” (realizowany z inicjatywy Fundacji Bertelsmanna przez Bibliotekę Uniwersytecką w Warszawie, Komisję Wydawnictw Elektronicznych SBP oraz INiB UMK) i „Login: biblioteka” (realizowany przez Bibliotekę Uniwersytecką w Warszawie w ramach Programu Rozwoju Bibliotek Fundacji Rozwoju Społeczeństwa Informacyjnego, Polsko-Amerykańskiej Fundacji Wolności oraz Fundacji Billa i Mellindy Gatesów). W 2018 r. rozpoczął pracę nad rozprawą doktorską zatytułowaną „Obszary zastosowania i potencjał rozwiązań należących do koncepcji smart city ze szczególnym uwzględnieniem sektora informacyjnego".

SŁOWA KLUCZOWE: Bibliologia i informatologia. Bibliometria. Inteligentne miasto. Metody badawcze. Smart city.

ABSTRAKT: Teza/cel - Przedmiotem artykułu jest analiza piśmiennictwa na temat koncepcji smart city z zakresu bibliologii i informatologii. Pod uwage wzięto wyłącznie artykuły z czasopism. Celem przeprowadzonych badań było stwierdzenie, bądź zaprzeczenie, obecności idei smart city w publikacjach z zakresu bibliologii i informatologii, wyłonienie pól zainteresowań badaczy w tym obszarze oraz zidentyfikowanie kierunków dalszych prac. Metoda - Zastosowano metodę analizy i krytyki piśmiennictwa. Przeprowadzono 
wyszukiwanie w źródłach zagranicznych (baza Web of Science Core Collection, baza Library, Information Science and Technology Abstracts, repozytorium E-LIS) i polskich (bibliograficzne bazy danych BN, w tym Polska Bibliografia Bibliologiczna oraz czasopisma z zakresu bibliologii i informatologii). Zebrany materiał poddano analizie formalnej i treściowej. Wnioski - Przeprowadzona analiza dowiodła dużego zainteresowania zagadnieniem smart city wśród badaczy z zakresu nauki o informacji i bibliologii na świecie oraz nieznacznego w Polsce. W rezultacie zainicjowanych badań udało się wyodrębnić obszary badawcze, w jakie wpisują się publikacje dotyczące potencjału rozwiązań smart city. Obserwując rozwój zainteresowania tym tematem w innych dziedzinach wiedzy, autor ostrożnie prognozuje, że w najbliższych latach zainteresowanie to obejmie także pole badawcze, jakim jest bibliologia i informatologia, a szerzej nauki o mediach i komunikowaniu.

\section{WPROWADZENIE}

Termin inteligentne miasto (ang. smart city) jest określeniem stosunkowo nowym, będącym przedmiotem zainteresowań przedstawicieli różnych dyscyplin naukowych. Niektórzy badacze utożsamiają go z pewnego rodzaju zjawiskiem czy koncepcją, będącą odpowiedzią na transformację, jaka dokonuje się w skali globalnej, dotyczącą budowy i funkcjonowania miast, inni - z szeroko rozumianą postawą otwartości na innowacje, identyfikowaną z umiejętnością szybkiego dostosowywania się do uwarunkowań zewnętrznych i wewnętrznych.

Jedną z najważniejszych koncepcji smart city sformułował Rudolf Giffinger w raporcie Smart cities. Ranking of European medium-sized cities, najważniejszym dokumencie dotyczącym inteligentnych miast, stanowiącym punkt odniesienia dla późniejszych modeli. Według niego, inteligentne miasto stanowi zespół sześciu kluczowych elementów, do których należą: inteligentna gospodarka (ang. smart economy), inteligentni mieszkańcy (ang. smart people), inteligentny urząd (ang. smart governance), inteligentna mobilność (ang. smart mobility), inteligentne środowisko (ang. smart environment) oraz inteligentne życie (ang. smart living) (Giffinger, 2007). Podobną koncepcję, różniącą się jedynie wskaźnikami, zaproponował Boyd Cohen, autor tzw. Smart City Wheel, modelu określającego główne gałęzie identyfikujące miasto (Gotlibowska, 2018). Oprócz zaproponowanego modelu Cohen dokonał klasyfikacji ośrodków miejskich aspirujących do bycia smart. Stwierdził, że na podstawie obserwacji wdrażanych rozwiązań i stopnia wykorzystania nowoczesnych technologii w procesie transformacji można wyróżnić trzy rodzaje inteligentnych miast (The 3 Generations, 2018). Inne koncepcje w dużej mierze opierają się na tym, co zostało nakreślone przez wyżej wymienionych badaczy. Cechą wspólną tych rozważań jest podkreślenie znaczenia nowych rozwiązań technologicznych w rozwoju ośrodków miejskich aspirujących do bycia smart.

Problematyka smart city jest od wielu lat zagadnieniem podejmowanym $\mathrm{w}$ piśmiennictwie $\mathrm{z}$ zakresu różnych dyscyplin, m.in. ekonomii, 
urbanistyki, gospodarki przestrzennej, architektury, zarządzania, ochrony środowiska czy informatyki. Kompleksowej analizy piśmiennictwa na ten temat dokonała Sławomira Hajduk w artykule pt. Analiza bibliometryczna koncepcji inteligentnego miasta w światowym piśmiennictwie naukowym (Hajduk, 2017). Dotąd nie przeprowadzono podobnego przeglądu literatury z zakresu bibliologii i informatologii. Niniejszy artykuł stanowi pierwszy krok w tym kierunku. W tym celu analizie (ilościowej i treściowej) poddano artykuły opublikowane na łamach światowych oraz polskich czasopism naukowych. Dążąc do dokonania bieżącego przeglądu i stanu badań, celowo zrezygnowano z analiz wydawnictw zwartych. Na wybór metody bibliometrycznej oraz metody analizy i krytyki piśmiennictwa wpływ miały ich poznawcze oraz utylitarne cele, a zwłaszcza fakt, że pierwsza z nich, pomaga gromadzić duże zasoby danych oraz dokonywać ich wieloaspektowych analiz, zaś druga - korygować istniejące teorie, scalać rozproszone informacje na dany temat i porządkować wiedzę.

\section{METODYKA BADAŃ WŁASNYCH}

Koncepcja smart city stanowi przedmiot badań przedstawicieli różnych dyscyplin naukowych. By zbadać, czy zainteresowanie to dotyczy także badaczy z zakresu bibliologii i informatologii, analizie poddano wyłącznie artykuły opublikowane na łamach światowych oraz polskich czasopism z tej dyscypliny. Odniesiono się wyłącznie do zawartości czasopism, co było umotywowane zamiarem dokonania bieżącego przeglądu i stanu piśmiennictwa z zakresu badanej problematyki.

Analizę piśmiennictwa zagranicznego przeprowadzono w kolekcji baz Web of Science Core Collection (dalej: WoS). Ograniczono się przy tym do trzech baz: Social Science Index, Arts and Humanities Citation Index oraz Emerging Sources Citation Index. W WoS posłużono się wyszukiwaniem według tematu (ang. topic), stosując cztery warianty wyrażenia wyszukiwawczego: „smart city”, ,smart cities” „,intelligent city”, „intelligent cities" ${ }^{\prime \prime}$. Taka strategia wyszukiwania umożliwiła penetrację następujących pól rekordów bibliograficznych: słowa kluczowe nadane przez autora, słowa kluczowe stworzone przez Clarivate Analytics, streszczenie i tytuł publikacji.

W celu uzupełnienia listy publikacji w kolejnym kroku dokonano poszerzenia materiału badawczego o opisy bibliograficzne pochodzące z dziedzinowej bazy danych Library, Information Science and Technology Abstracts (dalej: LISTA). Aby zachować metodykę wyszukiwania przyjętą podczas przeglądania zawartości bazy WoS, przeszukiwanie zasobów

${ }^{1}$ Dzięki użyciu czterech wariantów hasła „smart city”, uzyskano o 23 pozycje więcej, niż w przypadku ograniczenia się do dwóch wariantów: „smart city” lub „smart cities”. 
bazy LISTA przeprowadzono z użyciem tych samych haseł wyszukiwawczych, jak w przypadku przeszukiwania zasobów WoS oraz w oparciu o zawartość następujących pól rekordów: tytuł publikacji, słowa kluczowe nadane przez autora, hasło przedmiotowe stworzone przez twórców bazy i streszczenie.

Dążąc do kompletności w zakresie gromadzenia materiału, pod uwagę wzięto również zasoby międzynarodowego otwartego repozytorium z zakresu bibliotekoznawstwa i informacji naukowej Eprints in Library and Information Science (dalej: E-LIS). Repozytorium to przeszukano przy użyciu hasła przedmiotowego: „smart city”. Taka strategia nie przyniosła żadnych rezultatów. W związku z tym w kolejnej próbie postanowiono zastosować różne warianty poszukiwanego terminu: „smart cities”, „intelligent city”, „,intelligent cities”, „inteligentne miasto”, „inteligentne miasta".

Przeglądu polskich publikacji dokonano w oparciu o bazy danych bibliografii narodowej. W procesie przeszukiwania zasobów baz danych (Przewodnik Bibliograficzny, Bibliografia Zawartości Czasopism, Polska Bibliografia Bibliologiczna) posłużono się następującymi indeksami: „temat” oraz „słowo z opisu", stosując pięć wariantów wyrażenia wyszukiwawczego: "smart city", ,smart cities", „,intelligent city", ,inteligentne miasto", „,inteligentne miasta".

W związku z tym, że „Polska Bibliografia Bibliologiczna” od trzech lat nie jest aktualizowana, w celu powiększenia zbioru badawczego, weryfikacją objęto zawartość czasopism z zakresu bibliologii i informatologii znajdujących się w części B Wykazu czasopism naukowych nieposiadających wspótczynnika impact factor... MNiSW (Część B Wykazu czasopism, 2018).

Nadrzędnym celem przeprowadzonej analizy piśmiennictwa było stwierdzenie, bądź zaprzeczenie, obecności idei smart city w publikacjach z zakresu bibliologii i informatologii, wyłonienie pól zainteresowań badaczy w tym obszarze, a w konsekwencji zidentyfikowanie kierunków badań w tym obszarze.

Zainicjowane badania miały udzielić także odpowiedzi na następujące pytania:

1. Od kiedy notuje się zainteresowanie tematem smart city w literaturze z zakresu bibliologii i informatologii?

2. Czy na przestrzeni lat można wyróżnić okresy wzmożonego zainteresowania zagadnieniami smart city z zakresu bibliologii i informatologii?

3. Jak rozkłada się zainteresowanie problematyką inteligentnych miast wśród światowych i polskich badaczy?

4. Jak może kształtować się zainteresowanie zagadnieniem smart city w obszarze bibliologii i informatologii w najbliższej przyszłości? 
5. Jakie zagadnienia szczegółowe dotyczące inteligentnych miast rozpatrywane są na łamach literatury fachowej z zakresu bibliologii i informatologii?

Poza zainteresowaniem znalazły się z kolei takie kwestie, jak: analiza liczby cytowań dla pojedynczych publikacji, identyfikacja afiliacji autorów analizowanych publikacji oraz analiza pokrewnych tematów badawczych, które poruszane były równocześnie z tematyką smart city.

Dla potrzeb badań przygotowano kilkuetapowy model poszukiwań literatury (por. Rys. 1).

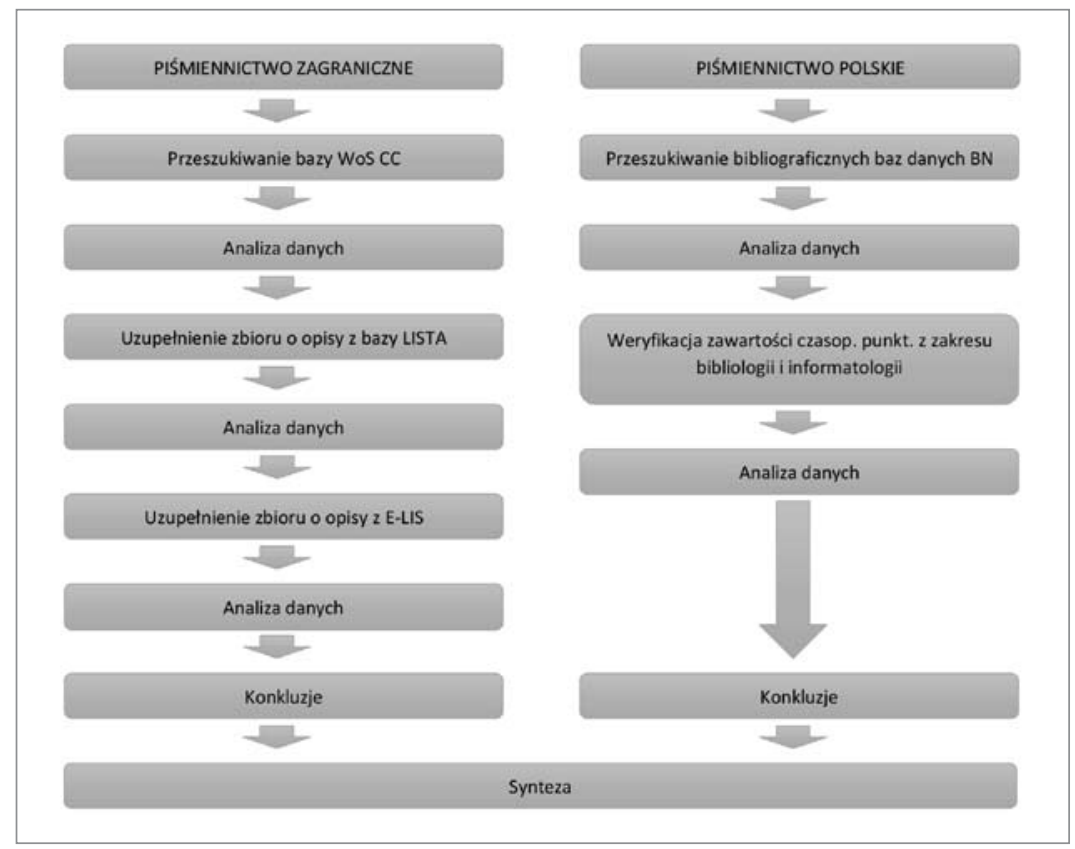

Rys. 1. Model poszukiwań literatury z zakresu bibliologii i informatologii

Źródło: Oprac. własne.

\section{OBECNOŚĆ PROBLEMATYKI SMART CITY NA ŁAMACH ZAGRANICZNYCH CZASOPISM Z ZAKRESU BIBLIOLOGII I INFORMATOLOGII}

Zainicjowanie procesu wyszukiwania w bazie WoS przyniosło rezultat w postaci 1248 opisów bibliograficznych, w tym 77 pozycji należących do obszaru bibliologii i informatologii.

Analiza zebranego materiału dowiodła, żenajwięcej artykułów znalezionych w bazie WoS zostało opublikowanych w czasopismach notowanych w bazie Journal Citation Report (dalej: JCR). Najlepszy pod tym względem okazał się "Government Information Quarterly" (14 artykułów). Jest to 
czasopismo międzynarodowe, na łamach którego publikowane są artykuły z zakresu polityki, technologii informacyjnych, administracji publicznej i społeczeństwa. Periodyk koncentruje się głównie na kwestiach dotyczących przepływu i dostępności informacji rządowych. Na drugim miejscu uplasowało się czasopismo „Social Science Computer Review” (9 artykułów), w którym znaleźć można artykuły dotyczące zastosowania informatyki w naukach społecznych. Wśród najczęściej omawianych zagadnień dominują: sztuczna inteligencja, biznes, obliczeniowa teoria nauk społecznych, wspomagane komputerowo badania ankietowe, komputerowa analiza jakościowa, symulacja komputerowa, modelowanie ekonomiczne, publikacja elektroniczna, systemy informacji geograficznej, oprzyrządowanie i narzędzia badawcze, administracja publiczna, wpływ społeczny informatyki i telekomunikacji oraz ocena oprogramowania. Trzeci pod względem liczby opublikowanych prac z zakresu informatologii i bibliologii okazał się periodyk „Információs Társadalom” (7 artykułów) - węgierskie czasopismo naukowe, poświęcone badaniom społeczeństwa informacyjnego. Ukazują się w nim prace o zasięgu międzynarodowym oraz lokalnym, które dodatkowo są deponowane w repozytorium. Szczegółowe dane na temat liczby artykułów w poszczególnych czasopismach zidentyfikowanych w bazach WoS przedstawiono w tabeli 1.

Tabela 1

Tytuły czasopism z zakresu bibliologii i informatologii zidentyfikowane na podstawie rekordów bazy WoS CC wraz z liczbą wyszukanych w nich artykułów

\begin{tabular}{|c|c|c|}
\hline Tytuł czasopisma & $\begin{array}{c}\text { Liczba } \\
\text { publikacji }\end{array}$ & $\begin{array}{c}\text { Obecność } \\
\text { w bazie JCR }\end{array}$ \\
\hline „Government Information Quarterly” & 14 & tak \\
\hline „Social Science Computer Review” & 9 & tak \\
\hline „Információs Társadalom” & 7 & tak \\
\hline $\begin{array}{l}\text { "International Journal of Public Administration in the Digital } \\
\text { Age" }\end{array}$ & 7 & nie \\
\hline „Telematics and Informatics" & 6 & tak \\
\hline „International Journal of Electronic Government Research" & 5 & nie \\
\hline „Telecommunications Policy” & 4 & tak \\
\hline "Information - Wissenschaft und Praxis" & 3 & nie \\
\hline „El Profesional de la Información” & 3 & tak \\
\hline „International Journal of Geographical Information Science” & 2 & tak \\
\hline „Journal of Global Information Management" & 2 & tak \\
\hline „Transforming Government People Process and Policy” & 2 & nie \\
\hline „Annals of Library and Information Studies" & 1 & nie \\
\hline „Cuadernos de Documentacion Multimedia” & 1 & nie \\
\hline „Informacao \& Sociedade: Estudos” & 1 & tak \\
\hline
\end{tabular}




\begin{tabular}{|l|c|c|}
\hline "Information Processing Management” & 1 & tak \\
\hline „Information Systems Journal” & 1 & tak \\
\hline „Information Technology for Development” & 1 & tak \\
\hline „International Journal of Information Management” & 1 & tak \\
\hline "Journal of Organizational and End User Computing” & 1 & tak \\
\hline „,Knowledge Management Research \& Practice” & 1 & tak \\
\hline „Libri" & 1 & tak \\
\hline "Scientometrics" & 1 & tak \\
\hline "Social Science information Sur Les Sciences Sociales” & 1 & tak \\
\hline "South African Journal of Information Management” & 1 & nie \\
\hline
\end{tabular}

Źródło: Oprac. własne.

W wyniku przeszukiwania zasobów bazy LISTA otrzymano zbiór liczący 119 dokumentów. Z rezultatów wyszukiwania wyeliminowano: dokumenty odnalezione wcześniej w bazie WoS (łącznie 27 pozycji), opisy dublujące się w obrębie samej bazy LISTA (pięć rekordów), opisy niemerytorycznych ${ }^{2}$ artykułów redakcyjnych (osiem), opisy sprawozdań z konferencji (jeden), opisy niemerytorycznych recenzji książek (13) oraz opisy artykułów tematycznie niezwiązanych z badaną problematyką (dwa). W rezultacie otrzymano 63 nowe publikacje.

Analiza materiału badawczego, zebranego w toku przeszukiwania zasobów bazy danych LISTA, przebiegała podobnie, jak w przypadku artykułów znalezionych w bazie WoS. Najwięcej artykułów odnaleziono w czasopiśmie „Information Polity: The International Journal of Government \& Democracy in the Information Age" (13 pozycji), które nie jest rejestrowane $\mathrm{w}$ bazie JCR. Periodyk ten jest wydawany $\mathrm{z}$ myślą o przedstawicielach środowiska naukowego, jak i praktykach. Publikuje prace z zakresu szeroko pojętych nauk społecznych, uwzględniających takie zagadnienia jak: polityka publiczna, zarządzanie publiczne, administracja publiczna, politologia, systemy informacyjne, informatyka, medioznawstwo, filozofia, socjologia, prawo, ekonomia. Stanowi także wartościowe źródło informacji na temat wykorzystania technologii informacyjno-komunikacyjnych $\mathrm{w}$ administracji. $\mathrm{W}$ tej kwestii najwięcej prac porusza zagadnienia: innowacji, polityki publicznej $\mathrm{w}$ erze informacji, wpływu ICT na instytucje publiczne, mediów społecznościowych, e-partycypacji, świadczenia usług cyfrowych, wymiany informacji, cyberbezpieczeństwo (About Journal, 2018). Drugie miejsce pod względem liczby publikacji zajęło notowane w bazie JCR czasopismo „Information Systems” (8 artykułów). Jest to źródło informacji na temat projektowania i wdrażania ję-

${ }^{2} \mathrm{Z}$ badań wykluczono artykuły, których treść ograniczała się do wprowadzenia w tematykę poszczególnych numerów czasopism lub sprawozdania programów zakończonych konferencji. 
zyków, modeli danych, modeli procesów, algorytmów, oprogramowania i sprzętu przeznaczonego dla systemów informatycznych. Obszary tematyczne artykułów publikowanych na łamach tego tytułu obejmują kwestie zarządzania danymi, a także zagadnienia związane $\mathrm{z}$ wyszukiwaniem informacji, zarządzaniem procesami biznesowymi, semantyką WWW oraz wizualnymi i dźwiękowymi systemami informatycznymi (Information Systems, 2018). Na trzecim miejscu uplasował się, zidentyfikowany już w bazie WoS, tytuł „First Monday” (5 pozycji). Szczegółowe dane na temat liczby artykułów odnalezionych w czasopismach zaindeksowanych $\mathrm{w}$ bazie LISTA zawarto $\mathrm{w}$ tabeli 2.

Tabela 2

Tytuły czasopism zidentyfikowane na podstawie rekordów bazy Library, Information Science and Technology Abstracts wraz z liczbą wyszukanych w nich artykułów

\begin{tabular}{|c|c|c|}
\hline Tytuł czasopisma & $\begin{array}{c}\text { Liczba } \\
\text { publikacji }\end{array}$ & $\begin{array}{c}\text { Obecność } \\
\text { w bazie JCR }\end{array}$ \\
\hline $\begin{array}{l}\text { "Information Polity: The International Journal of Government } \\
\text { \& Democracy in the Information Age" }\end{array}$ & 13 & nie \\
\hline „Information Systems" & 8 & tak \\
\hline „First Monday” & 5 & nie \\
\hline $\begin{array}{l}\text { "Proceedings of European Conference on Knowledge Mana- } \\
\text { gement" }\end{array}$ & 4 & nie \\
\hline „CLIP Upadte” & 2 & nie \\
\hline "Current Reviews for Academic Libraries" & 2 & nie \\
\hline „Journal of Intellectual Capital” & 2 & nie \\
\hline „Publishers Weekly" & 2 & nie \\
\hline „Universal Access in the Information Society" & 2 & nie \\
\hline „Information, Communication \& Society” & 1 & nie \\
\hline „Information and Communication Technology Law” & 1 & nie \\
\hline „Against the Grain” & 1 & nie \\
\hline "AIB Studi" & 1 & nie \\
\hline „APLIS" & 1 & nie \\
\hline "Biblioteche Oggi" & 1 & nie \\
\hline „Booklist" & 1 & nie \\
\hline $\begin{array}{l}\text { "Bullettin of the Association for Information Science } \\
\text { \& Technology" }\end{array}$ & 1 & nie \\
\hline „Electronic Government: An International Journal” & 1 & nie \\
\hline „Forum SIGIR” & 1 & nie \\
\hline „Hi Tech News" & 1 & nie \\
\hline „Information Design Journal” & 1 & nie \\
\hline „Information Scotland" & 1 & nie \\
\hline
\end{tabular}




\begin{tabular}{|l|c|c|}
\hline "Information Services \& Use” & 1 & nie \\
\hline „Informatologia” & 1 & nie \\
\hline "Journal of Information Processing \& Management” & 1 & tak \\
\hline "Journal of Information Science \& Technology Association” & 1 & nie \\
\hline "Journal of Organizational \& End User Computing” & 1 & tak \\
\hline „,KM World” & 1 & nie \\
\hline „Library Journal” & 1 & tak \\
\hline „Mousaion” & 1 & nie \\
\hline "Scandinavian Public Library Quarterly" & 1 & nie \\
\hline "SRELS. Journal of Information Management” & 1 & nie \\
\hline
\end{tabular}

Źródło: Oprac. własne.

Zebrany materiał badawczy pozyskany $\mathrm{w}$ wyniku przeszukiwania obu baz danych uzupełniono o pozycje znalezione w repozytorium E-LIS. $\mathrm{W}$ rezultacie odnaleziono 2 tytuły: 1 poster konferencyjny oraz 1 artykuł.

\section{OBECNOŚĆ PROBLEMATYKI SMART CITY NA ŁAMACH POLSKICH CZASOPISM Z ZAKRESU BIBLIOLOGII I INFORMATOLOGII}

W wyniku przeszukiwania zasobów bibliograficznych baz danych Biblioteki Narodowej otrzymano 43 rekordy. Wśród nich był tylko 1 artykuł polskiego autora (Luterek, 2018), dotyczący kwestii smart city rozpatrywanej na gruncie bibliologii i informatologii, opublikowany w języku angielskim. Artykuł ten ukazał się na łamach czasopisma "Zagadnienia Informacji Naukowej. Studia Informacyjne".

Analiza spisów treści periodyków oraz ich zawartości (szczególną uwagę zwrócono na numery czasopism ukazujące się w latach 2011-2018, czyli $\mathrm{w}$ okresie największego zainteresowania tym tematem na łamach zagranicznego piśmiennictwa naukowego) pozwoliła na uzupełnienie zbioru badawczego o 1 artykuł (Jacobfeuerborn, 2004).

\section{WNIOSKI PŁYNĄCE Z ILOŚCIOWEJ ANALIZY PIŚMIENNICTWA Z ZAKRESU BIBLIOLOGII I INFORMATOLOGII}

W efekcie badaniami objęto łącznie 143 artykuły, opublikowane od 1998 r. (pierwsze ujęcie idei smart city w literaturze) do 2018 r. Analizie poddano zawartość streszczeń dołączonych do artykułów oraz ich pełne teksty ${ }^{3}$.

\footnotetext{
${ }^{3}$ W przypadku 22 artykułów wydanych w języku japońskim, hiszpańskim, portugalskim, niemieckim, chorwackim, perskim, włoskim i węgierskim badania ograniczono do analizy treści anglojęzycznych streszczeń.
} 
W badanym zbiorze najwięcej artykułów ukazało się w latach 20162018 (98) oraz w latach 2012-2015 (40). W latach: 1998, 2000, 2004, 2005 i 2010 opublikowano po jednym artykule, natomiast w latach: 1999, 2001, 2002, 2003, 2006, 2007, 2008, 2009 i 2011 nie odnotowano żadnej publikacji (por. Wykres 1).

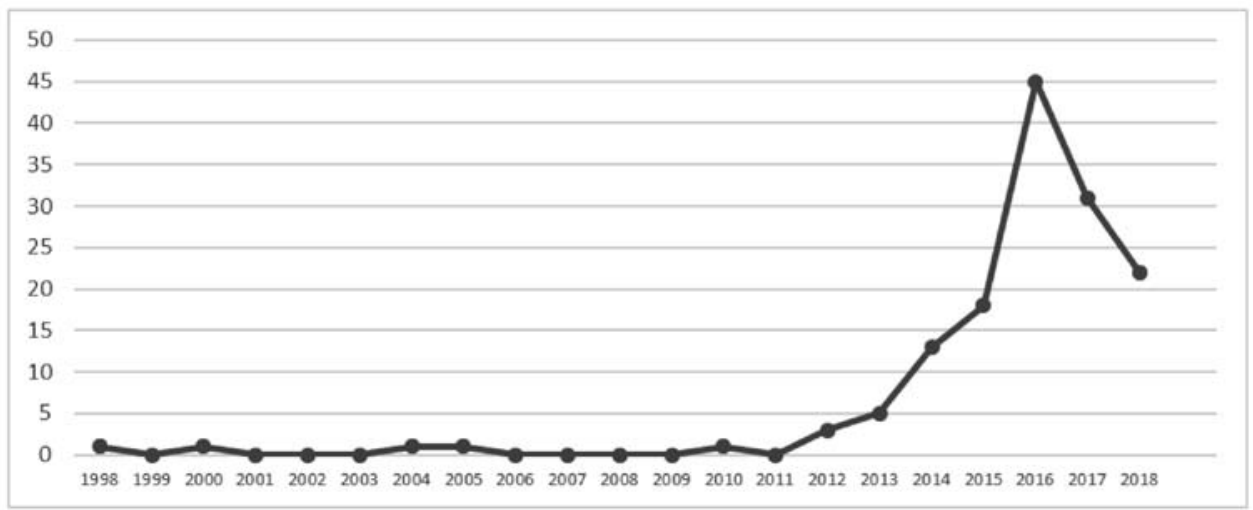

Wykres 1. Problematyka smart city na łamach publikacji z zakresu bibliologii i informatologii w latach 1998-2018

Źródło: Oprac. własne.

Analiza dat wydania wszystkich znalezionych artykułów dowodzi, że termin smart city po raz pierwszy pojawił się w polskiej literaturze bibliologicznej w 1998 r. W kolejnych latach problematyka inteligentnych miast nie była podejmowana $\mathrm{w}$ pracach naukowych lub zajmowano się nią sporadycznie. Sytuacja zmieniła się w 2012 r. Wówczas pojawiły się kolejne prace na ten temat. Największą koncentrację uwagi na tym zagadnieniu obserwuje się $\mathrm{w}$ trzech ostatnich latach (2015-2018), a zwłaszcza w 2016 r. -45 tekstów. Należy zauważyć, że w przypadku 2018 r., analizie poddano wyłącznie publikacje wydane $w$ jego pierwszej połowie, stąd na wykresie widoczny spadek liczby publikacji. Mając na uwadze rosnące zainteresowanie tematyką smart city w kontekście bibliologii i informatologii, można przypuszczać, że liczba artykułów będzie rosła również w najbliższych latach.

Na podstawie zebranego materiału można wywnioskować, że najwięcej artykułów zostało opublikowanych w języku angielskim (121). Pozostałe zostały opublikowane w językach: węgierskim (7), hiszpańskim (4), niemieckim (4), włoskim (2), japońskim (2), chorwackim (1), perskim (1) i portugalskim (1) (por. Wykres 2).

Badanie zgromadzonego materiału pod względem językowym wykazało wyraźną dominację w zbiorze dokumentów opublikowanych w ję- 


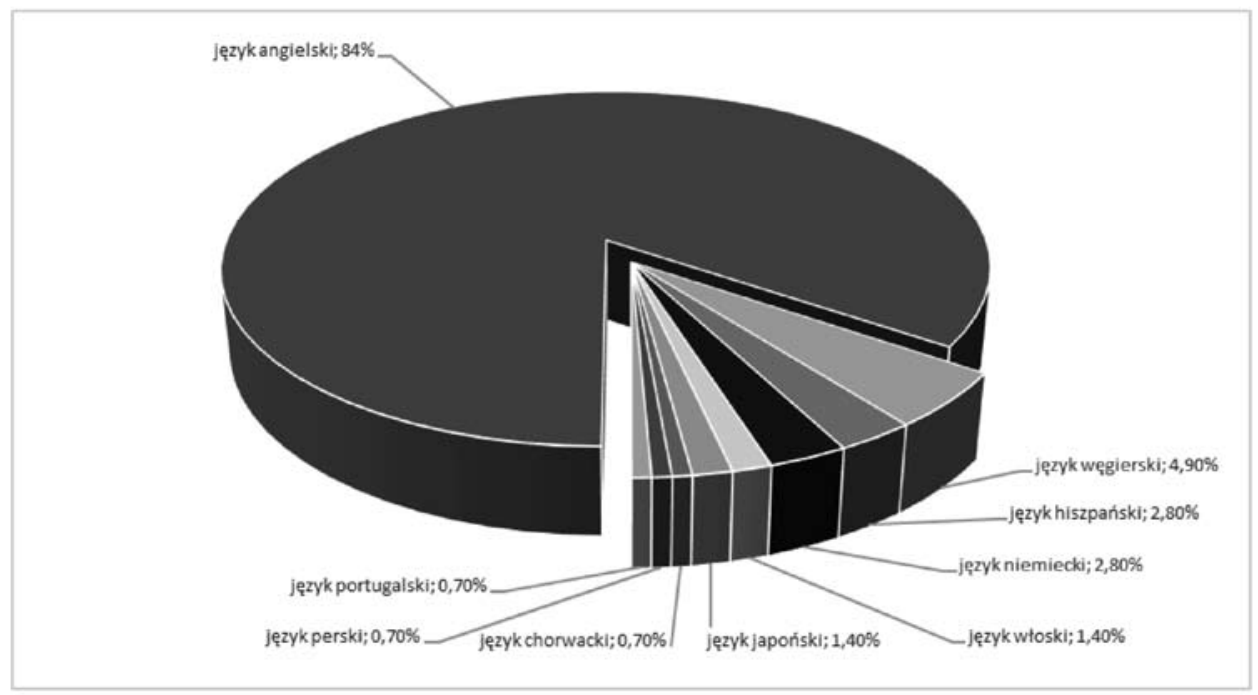

Wykres 2. Artykuły na temat smart city według języka publikacji

Źródło: Oprac. własne.

zyku angielskim (121). Taki stan rzeczy jest przede wszystkim wynikiem wzmożonego zainteresowania tematyką smart city wśród badaczy m.in. z Wielkiej Brytanii, Niemiec, Indii czy Stanów Zjednoczonych, którzy publikują teksty w języku angielsku.

Jak udało się ustalić, inteligentne miasto jest tematem często podejmowanym w zagranicznych opracowaniach z zakresu różnych dyscyplin naukowych, w tym bibliologii i informatologii. W tym kontekście dziwi fakt, że do tej pory na gruncie polskim powstało tak mało prac dotyczących tej tematyki. Pozostaje mieć nadzieję, że niniejszy artykuł wypełni tę lukę.

\section{ASPEKTY SMART CITY PORUSZANE NA ŁAMACH LITERATURY Z ZAKRESU BIBLIOLOGII I INFORMATOLOGII}

Analiza zawartości treściowej wszystkich znalezionych artykułów dowiodła, że na łamach zagranicznych i polskich publikacji z zakresu bibliologii i informatologii idea smart city była rozpatrywana w różnych aspektach. Zgromadzony materiał badawczy pozwolił na identyfikację następujących obszarów tematycznych:

- obszar 1: smart city jako nowa koncepcja funkcjonowania i rozwoju miasta,

- obszar 2: inteligentne miasto jako mechanizm generowania, optymalizacji i oceny jakości informacji, danych, zasobów i systemów informacyjnych, 
- obszar 3: smart city jako idea wspierana przez biblioteki i inne instytucje sektora kultury,

- obszar 4: smart city jako miasto rozwijające się dzięki partycypacji społecznej i właściwemu zarządzaniu wiedzą.

Największą grupę pod względem liczebnym (61 pozycji) utworzyły artykuły należące do obszaru czwartego. Wyodrębniono w nim trzy kategorie:

1. Artykuły dotyczące włączania mieszkańców w procesy decyzyjne dotyczące usług miejskich oraz odnoszące się do kwestii wykorzystania mediów społecznościowych w celu zdobycia opinii mieszkańców na temat wprowadzanych rozwiązań (12 artykułów), np. projekty miejskie angażujące obywateli w zarządzanie miastem (Webster, 2018), badanie nastrojów społecznych za pomocą popularnych serwisów umożliwiających publikowanie treści (Estévez-Ortiz, 2016), projektowanie aplikacji wspierających e-partycypację (Ortner, 2016).

2. Artykuły opisujące projekty realizowane w następujących obszarach: wiedza, administracja publiczna, zdrowie, transport, energetyka, ochrona środowiska (37 pozycji), np. kształcenie urzędników inteligentnych miast (Pînzaru, 2018), wymiana informacji między jednostkami administracji publicznej za pomocą wdrażanych rozwiązań ICT (Gil-Garcia, 2012), wdrażanie systemu monitorującego ruch uliczny (Reddy, 2018), inteligentne systemy zarządzania energią (Shu, 2016).

3. Rozwiązania technologiczne projektowane z myślą o mieszkańcach inteligentnych miast (12 artykułów), np. aplikacje wykorzystujące dane pochodzące z telefonów komórkowych (Steenbruggen, 2015), przykłady dobrych praktyk w zakresie projektowania elektronicznych usług miejskich (Hsiaoping, 2017).

W drugiej grupie znalazły się artykuły z obszaru pierwszego (46 pozycji), omawiające zagadnienie smart city w sposób ogólny oraz na przykładzie konkretnych przypadków. W tym podzbiorze wyodrębniono dwie kategorie:

1. Prace o charakterze definicyjnym (32 artykuły), np. pochodzenie terminu smart city i rozważania metodologiczne (Barth, 2018), zagadnienia dotyczące nowoczesnego zarządzania miastem przy wsparciu technologii informacyjno-komunikacyjnych (Pereira, 2018).

2. Artykuły ukazujące efekty wdrażania rozwiązań „smart” w konkretnych miastach (14 pozycji), np. amerykańskie praktyki w dziedzinie wdrażania rozwiązań z zakresu e-government (Scholl, 2016), mechanizmy kontrolujące obywateli w Chinach (Kshetri, 2017).

Na trzeciej pozycji, pod względem liczby artykułów ujętych w danej grupie, uplasował się obszar drugi (20 artykułów), w którym zidentyfikowano publikacje relacjonujące stan badań w zakresie wykorzystania dużych liczb danych. W tej grupie umieszczono także artykuły porusza- 
jące problem cyberbezpieczeństwa. W tym obszarze również dokonano dodatkowego podziału na dwie kategorie:

1. Artykuły omawiające kwestię wykorzystania danych $\mathrm{w}$ procesie projektowania usług dla obywateli (15 artykułów), np. wskaźniki służące do oceny wykorzystania danych otwartych (Abella, 2014), analiza tzw. danych miejskich i ich wykorzystanie w zarządzaniu miastem (Calegari, 2016).

2. Artykuły dotyczące bezpieczeństwa i ochrony danych wrażliwych (5 artykułów), np. ochrona użytkowników przed cyberatakami (Li, 2018), ochrona tzw. danych wrażliwych (Belanche, 2015).

Ostatni - najmniej liczny zbiór (16 artykułów) - utworzyły prace z obszaru trzeciego, poświęcone bibliotekom i instytucjom z sektora informacyjnego omawianym w kontekście idei smart city. Wśród nich wydzielono trzy kategorie artykułów:

1. Artykuły dotyczące możliwości badania bibliotek jako instytucji smart (6 artykułów),

2. Artykuły o roli bibliotek w promowaniu zrównoważonego rozwoju (1 artykuł), np. próba konceptualizacji inteligentnego systemu informacyjnego odpowiadającego potrzebom użytkowników (Tripathi, 2016).

3. Artykuły na temat znaczenia bibliotek w kształtowaniu świadomości mieszkańca nowoczesnego miasta (9 pozycji), np. biblioteka jako instytucja ukierunkowana na dostęp do wiedzy (Solimine, 2013), mobilność treści niematerialnych, bibliotekarz $\mathrm{w}$ roli pośrednika pomiędzy wiedzą i użytkownikiem informacji, propozycje najlepszych rozwiązań dla nowoczesnych bibliotek publicznych (Crasta, 2013).

\section{WNIOSKI PŁYNĄCE Z ANALIZY TREŚCIOWEJ PIŚMIENNICTWA}

Tematyką najczęściej poruszaną na łamach zagranicznych i polskich publikacji bibliologicznych były kwestie związane z wykorzystywaniem nowych rozwiązań technologicznych w takich obszarach jak: wiedza, administracja, transport, ochrona środowiska, zdrowie oraz zagadnienia dotyczące partycypowania obywateli miast $\mathrm{w}$ procesach decyzyjnych (61 artykułów). Szczególnie dużo prac dotyczy wdrażania projektów mających na celu usprawnienie funkcjonowania istniejących systemów, tworzenia alternatywnych narzędzi czy projektowania aplikacji wykorzystujących informacje agregowane z serwisów społecznościowych. Silną reprezentację $\mathrm{w}$ obszarze czwartym mają także prace na temat wprowadzania usprawnień w administracji publicznej przy pomocy technologii informacyjno-komunikacyjnej (platformy kontaktu z obywatelem, aplikacje alarmujące o zagrożeniach).

W drugim, pod względem liczby artykułów, obszarze umieszczono publikacje (46 pozycji), których autorzy rozpatrują zjawisko smart city 
w kontekście ogólnym, zwracając uwagę na rosnącą popularność rozwiązań smart i wskazując kierunki rozwoju prac badawczych w tym zakresie. Widoczne są liczne nawiązania autorów prac do artykułów $\mathrm{z}$ innych dyscyplin naukowych, w których zagadnienie inteligentnych miast zostało lepiej rozpoznane. Część publikacji relacjonuje wdrażanie dobrych praktyk w zakresie inteligentnych rozwiązań w miastach europejskich, azjatyckich oraz amerykańskich. Są także prace porównawcze, których autorzy postulują wypracowanie wspólnych rozwiązań w zakresie realizacji idei smart city.

Artykuły dotyczące wykorzystania dużych liczb danych znalazły się w kolejnej grupie tematycznej (20 pozycji). To ważna kwestia, często podejmowana $\mathrm{w}$ pracach dotyczących tworzenia infrastruktury miejskiej, której odpowiednie zaprojektowanie, zwiększa interaktywność i jakość życia mieszkańców. Analiza danych pochodzących z różnych źródeł pomaga rozpoznać potrzeby użytkowników, wyciągnąć odpowiednie wnioski i w konsekwencji zainicjować odpowiednie działania.

Ostatni zbiór reprezentują publikacje (16 artykułów) poświęcone rozwiązaniom smart w instytucjach sektora informacyjnego. Z punktu widzenia informatologii i bibliologii są to prace wyjątkowo cenne, podejmujące tematykę smart city po raz pierwszy w odniesieniu do bibliotek. Materiał badawczy w tym zakresie jest wyjątkowo ubogi. Poza kilkoma pracami, których autorzy wyznaczają kierunki badań bibliotek „smart”, próżno szukać artykułów traktujących o tym zagadnieniu w publikacjach naukowych. Mimo to warto podkreślić, że materiał badawczy zgromadzony w obszarze trzecim umożliwił rozpoznanie zjawiska smart city w ujęciu bibliologii i informatologii i pozwolił na jego zdefiniowanie (por. Wykres 3).

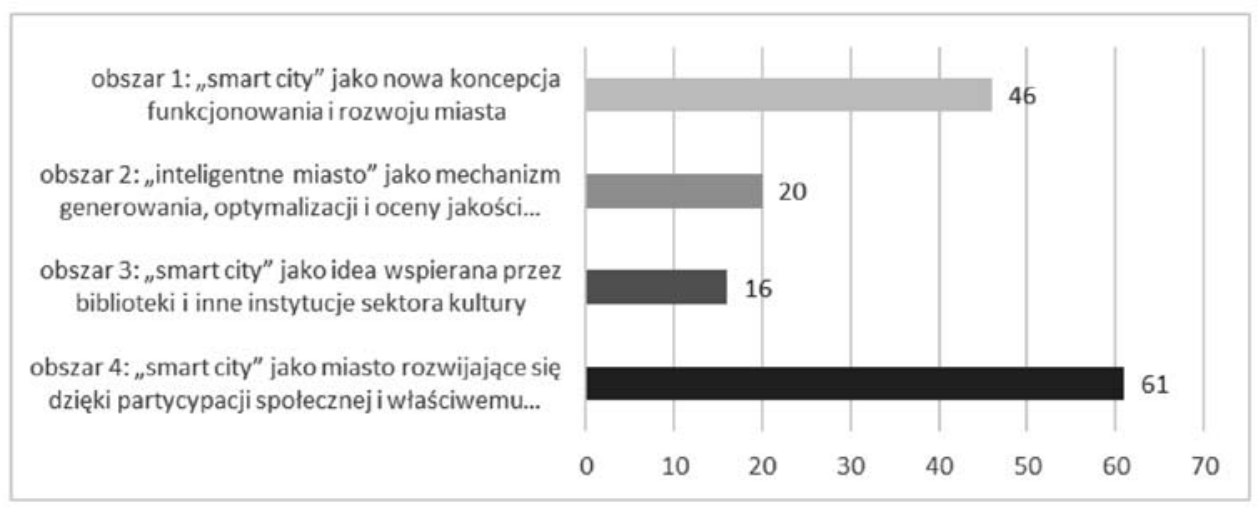

Wykres 3. Aspekty smart city poruszane na łamach zagranicznych i polskich publikacji bibliologicznych

Źródło: Oprac. własne. 


\section{KONCEPCJA INTELIGENTNEGO MIASTA W PERSPEKTYWIE BIBLIOLOGICZNEJ - PRÓBA WYZNACZENIA KIERUNKÓW BADAŃ}

Biblioteki odgrywają ważną rolę w gospodarce opartej na wiedzy. Nie tylko zaspokajają potrzeby mieszkańców miast, lecz także służą sektorowi prywatnemu, zwłaszcza małym i średnim przedsiębiorstwom. W nowoczesnym mieście, którego funkcjonowanie w dużej mierze uzależnione jest od sukcesywnie wdrażanych rozwiązań technologicznych, instytucje sektora informacyjnego mogą pełnić rolę wyspecjalizowanych ośrodków wiedzy. Jak sugeruje Sneha Tripathi, dzięki zastosowaniu łatwo dostępnych narzędzi ICT (komputery, smartfony), realizowanie potrzeb informacyjnych użytkowników może być o wiele prostsze (Tripathi, 2016).

Ważną rolą bibliotek jest wspieranie rozwoju gospodarczego poprzez świadczenie usług w zakresie doradztwa, wsparcia, sporządzania sprawozdań, dokumentacji czy prowadzenia działalności infobrokerskiej (wywiad rynkowy, wywiad strategiczny, doradztwo w zakresie informacji patentowej) (Mainka, 2013). Nie bez znaczenia są także wciąż rosnące potrzeby zwykłych mieszkańców w zakresie dostępu do informacji, o czym w swoim artykule pisze Madel Crasta, zwracając uwagę na konieczność uwzględniania bibliotek $\mathrm{w}$ procesie projektowania nowoczesnych miast (Crasta, 2013).

Zmieniająca się rola instytucji sektora informacyjnego powoduje zmiany w strukturze odbiorców ich usług. Jak zauważa Giovanni Solimine, biblioteki coraz częściej zamieniają się w ośrodki zapobiegające wykluczeniu cyfrowemu. Dostarczając wysokojakościowej wiedzy i wdrażając innowacyjne rozwiązania, otwierają się na potrzeby wymagających użytkowników. Zapewniają także dostęp do treści o zasięgu globalnym (Solimine, 2013). Ważnym przykładem dobrej praktyki w tym zakresie są działania zainicjowane w 1998 r. w Singapurze. Polegały one na stworzeniu sieci cyfrowych bibliotek publicznych TiARA (Timely Information for All, Relevant and Affordable), zapewniających użytkownikom dostęp do akademickich i profesjonalnych baz danych (Tan, 1998). Ken Wheaton i Art Murray zwracają uwagę na jeszcze jedną funkcję bibliotek w nowocześnie zaprojektowanym mieście. Jest to pielęgnowanie tradycji, istotne przede wszystkim z punktu widzenia rdzennych mieszkańców dużych metropolii (Murray \& Wheaton, 2012). Z kolei Mariusz Luterek podkreśla potrzebę budowania relacji, przede wszystkim dzięki wykorzystaniu mediów społecznościowych (Facebook, YouTube, Twitter). Takie działanie ułatwia kontakt z użytkownikiem korzystającym $\mathrm{z}$ usług biblioteki w sposób zdalny (Luterek, 2018).

Reasumując, realizacja strategii smart city może wpływać na biblioteki i ośrodki informacji mobilizująco, zachęcając je do współuczestniczenia w procesie budowania inteligentnego miasta. Dostęp do wysokojakościo- 
wej i pełnowartościowej informacji może mieć duży wpływ na osiągnięcie postępu w określonych gałęziach gospodarki. Ian Martin Johnson zaproponował zdefiniowanie roli bibliotek publicznych $\mathrm{w}$ inteligentnym mieście w oparciu o wskaźniki sformułowane wcześniej przez R. Giffingera (Giffinger, 2007):

1. „Inteligentni ludzie”: rozwój inteligentnego miasta zależy od rozwoju kapitału ludzkiego, czyli pracowników wiedzy, odpowiednio wyedukowanych, gotowych do podnoszenia swoich kwalifikacji, kreatywnych, aktywnie działających w życiu publicznym. Biblioteka może ich w tym wspierać.

2. „Inteligentna gospodarka”: odpowiednio wykwalifikowani pracownicy warunkują rozwój gospodarczy. W związku z tym potrzebna jest integracja sektora informacyjnego i biznesowego, aby wyposażyć ludzi $\mathrm{w}$ potrzebną wiedzę. Biblioteka publiczna samodzielnie nie jest $\mathrm{w}$ stanie tego zrobić. Potrzebna jest efektywna współpraca między wszystkimi typami bibliotek, współpracującymi z przedstawicielami sektora biznesowego. Odpowiednia infrastruktura informacyjna szybciej zaspokoi potrzeby mieszkańców „inteligentnego miasta”.

3. „Inteligentna mobilność": właściwie zaplanowana infrastruktura transportowa i telekomunikacyjna podnosi standard życia mieszkańców nowoczesnych miast. Biblioteki i centra badawcze mogą przekazywać wiedzę na temat nowych rozwiązań technologicznych oraz zapewniać dostęp do Internetu dla mieszkańców zagrożonych wykluczeniem informacyjnym.

4. „Inteligentne środowisko”: nowoczesne miasto musi rozwijać się w taki sposób, żeby w jak najmniejszym stopniu ingerować w środowisko. Odpowiednia edukacja w tym zakresie, prowadzona przez biblioteki, może pomóc w osiągnięciu tego celu.

5. „Inteligentny rząd”: mieszkańcy inteligentnych miast są aktywnymi uczestnikami życia publicznego. Miasto powinno zapewnić każdemu dostęp do informacji na temat swojej działalności poprzez odpowiednio zredagowane serwisy internetowe, platformy informacyjne oraz dedykowane aplikacje. Rolą biblioteki jest ułatwienie dostępu do informacji publicznej oraz wspieranie mieszkańców angażujących się w życie miasta.

6. „Inteligentne życie”: biblioteka może pełnić w mieście funkcję kulturalną (popularyzacja czytelnictwa, organizowanie odczytów i spotkań autorskich), edukacyjną (szkolenia podnoszące kompetencje użytkowników), społeczną (integracja lokalnej społeczności) i tym samym przyczyniać się do polepszenia jakości życia mieszkańców (Johnson, 2012). 


\section{PODSUMOWANIE}

Smart city jest zagadnieniem do tej pory rzadko badanym w kontekście bibliologii i informatologii. Za granicą najważniejsze prace $w$ tym zakresie prowadzą naukowcy z Wydziału Nauk Informacyjnych w Heinrich-Heine -Universität Düsseldorf w Niemczech (Wolfgang G. Stock, Agnes Mainka, Sarah Hartmann, Lisa Orszullok, Isabella Peters, Anika Stallmann). Przeanalizowali oni szczegółowo kwestię usług świadczonych przez biblioteki tradycyjne i cyfrowe w społeczeństwie wiedzy, w miastach nowego typu. Na gruncie polskim najbardziej kompleksowego przeglądu badań prowadzonych w zakresie tzw. inteligentnych miast na podstawie zagranicznej literatury naukowej dokonał M. Luterek. Przedstawił on definicję smart city oraz poruszył takie zagadnienia, jak: rola obywatela w inteligentnym mieście, wykorzystanie nowych technologii w rozwoju infrastruktury informacyjnej oraz funkcje bibliotek publicznych w rozwijającym się mieście nowego typu. Autor wykazał także, że dostępne piśmiennictwo z zakresu innych dyscyplin naukowych sporadycznie odnosi się do roli instytucji sektora informacyjnego, a rola bibliotek $\mathrm{w}$ tzw. inteligentnych miastach pozostaje niepodjętym tematem $\mathrm{w}$ literaturze $\mathrm{z}$ zakresu bibliologii i informatologii (Dorsch, 2017).

Za M. Luterkiem można więc przyjąć, że badania zjawiska smart city w kontekście bibliologii i informatologii powinny objąć następujące płaszczyzny:

- informetrię i naukometrię: określenie wskaźników, które pomogą zbadać inteligentne miasto od strony przepływu informacji,

- architekturę informacji: analiza struktury i systemów nawigacji internetowych serwisów społecznościowych,

- organizacje wiedzy i wyszukiwanie informacji: dostarczenie odpowiedniej wiedzy w każdym procesie decyzyjnym,

- zarządzanie wiedzą: odpowiednie zorganizowanie procesu rozpowszechniania i udostępniania informacji w społeczeństwie, ze szczególnym uwzględnieniem tzw. wiedzy jawnej (ang. explicit knowledge) o rozmaitej formie: dokumentów, podręczników, materiałów szkoleniowych, instrukcji oraz innych zgromadzonych zasobów,

- badanie użytkowników: ocena potrzeb informacyjnych,

- marketing informacyjny: informowanie o usługach oferowanych przez biblioteki i ośrodki informacji,

- socjologię informacji i etykę informacji: analiza społecznych konsekwencji „inteligentnej rewolucji” (np. wykluczenie cyfrowe),

- kompetencje informacyjne (ang. information literacy): likwidacja negatywnych skutków „inteligentnej rewolucji” (Luterek, 2018).

Spośród wyżej określonych kierunków jedno z ciekawszych wyzwań dla współczesnych badaczy inteligentnego miasta może stanowić badanie 
użytkowników informacji. Warto bliżej przyjrzeć się nie tylko kwestiom związanym z zaspokajaniem potrzeb informacyjnych mieszkańców, ale także innym zjawiskom, które czynią miasta nowoczesnymi, otwartymi na zmiany. Rola sektora informacyjnego ma istotne znaczenie w przypad$\mathrm{ku}$ miast pretendujących do bycia smart. To właśnie biblioteki i ośrodki kultury wspierają miasta $w$ ich rozwoju poprzez m.in.: wspieranie dziedzictwa miasta (dzielnicy, osiedla itd.); wzmacnianie partycypacji, w tym partycypacji obywatelskiej oraz wspieranie oddolnych inicjatyw mieszkańców. Powszechny dostęp do Internetu implikuje coraz swobodniejszą możliwość stosowania różnorodnych instrumentów (opartych na technologiach ICT) aktywizujących lokalne społeczności. Crowdsourcing, budżet obywatelski czy miejskie hackathony to nowoczesne mechanizmy dające mieszkańcom możliwość współtworzenia, dokonywania zmian, czy projektowania innowacyjnych rozwiązań. Ośmielają tych, którzy do tej pory nie wykazywali się społecznym zaangażowaniem oraz ułatwiają działania osobom, traktującym podejmowanie decyzji w sprawach związanych z najbliższym otoczeniem jako niezwykle ważny przywilej obywatelski.

\section{BIBLIOGRAFIA}

Abella, Alberto; Ortiz-de-Urbina-Criado, Marta; De-Pablos-Heredero, Carmen (2014). Meloda, a metric to assess open data reuse. El Profesional de la Información, vol. 23, iss. 6, pp. 582-588.

About Journal I Information Polity (2018) [online] [dostęp 10.11.2018]. Dostępny w WWW: $<$ https://informationpolity.com/about-journal $>$.

Barth, Julia; Fietkiewicz, Kaja J.; Gremm, Julia (2018). Informational urbanism. InformationWissenschaft Und Praxis, vol. 69, iss. 1, pp. 31-46.

Belanche, Daniel; Casalo-Arino, Luis Vicente; Perez-Rueda, Alfredo (2015). Determinants of multi-service smartcard success for smart cities. development: A study based on citizens' privacy and security perceptions. Government Information Quarterly, vol. 32, iss. 2, pp. 154-163.

Calegari, Gloria; Celino, Irene; Peroni, Diego (2016). City data dating: Emerging affinities between diverse urban datasets, Information Systems, vol. 57, pp. 223-240.

Crasta, Madel (2015). Biblioteche e sistemi territoriali: nuove tendenze. Biblioteche Oggi, vol. 33, iss. 2, pp. 3-7.

Część B Wykazu czasopism naukowych. czasopisma naukowe nieposiadające wspótczynnika impact factor (IF) wraz z liczba punktów przyznawanych za publikację w tych czasopismach (2018) [online] [dostęp 10.11.2018]. Dostępny w WWW: <https://www.gov.pl/documents/1068 557/1069061/2017_Cz\%C4\%99\%C5\%9B\% C4\%87_B.pdf/9afc82a2-6b2d-cf10-1e 29-a5ba15891693>.

Dorsch, Isabelle; Schlogl, Christian; Stock, Wolfgang. G (2017). Research Topics of the Information Science Departments in Dusseldorf and Graz, Information - Wissenschaft und Praxis, vol. 68, iss. 5-6, pp. 320-328.

Estévez-Ortiz, Francisco-Jose; Jiménez, Antonio García; Glösekötter, Peter (2016). Aplicación a las ciudades inteligentes del sentimiento de la gente en redes sociales. El Profesional de la Información, vol. 25, iss. 6, pp. 851-858.

Giffinger, Rudolf (2007). Smart cities. Ranking of European medium-sized cities [online] [dostęp 
10.11.2018]. Dostępny w WWW: <http://www.smart-cities.eu/download/smart_cities_ final_report.pdf $>$.

Gil-Garcia, J. Ramon (2012). Towards a smart State? Inter-agency collaboration, information integration, and beyond. Information Polity: The International Journal of Government $\mathcal{E}$ Democracy in the Information Age, vol. 17, iss. 3/4, pp. 269-280.

Gotlibowska, Katarzyna (2018). Propozycja modelu miasta inteligentnego (Smart City) opartego na zastosowaniu technologii informacyjno-komunikacyjnych w jego rozwoju. Rozwój Regionalny i Polityka Regionalna, nr 42, s. 67-80.

Government Information Quarterly (2018) [online] [dostęp 10.11.2018]. Dostępny w WWW: $<$ https://www.journals.elsevier.com/government-information-quar-terly>.

Hajduk, Sławomira (2017). Analiza bibliometryczna koncepcji inteligentnego miasta w światowym piśmiennictwie naukowym. Handel Wewnętrzny, nr 3(368), s. 301-312.

Hsiaoping, Yeh (2017). The effects of successful ICT-based smart city services: From citizens' perspectives. Government Information Quarterly, vol. 34, iss. 3, pp. 556-565.

Információs Társadalom (2018) [online] [dostęp 10.11.2018]. Dostępny w WWW: <http://informaciostarsadalom.infonia.hu/index.php/inftars>.

Information Systems - Journal - Elsevier (2018) [online] [dostęp 10 listopada 2018]. Dostępny w WWW: <https://www.journals.elsevier.com/information-systems>.

Jacobfeuerborn, Bruno; Muraszkiewicz, Mieczysław (2014). Towards Smart Cities. Informational Aspects. PTINT Praktyka i Teoria Informacji Naukowej i Technicznej, t. 22, nr 1, pp. 38-46.

Johnson, Ian M. (2012) Smart Cities, Smart Libraries, and Smart Librarians. Shanghai International Library Forum, Shanghai (China), 18-19 July 2012 [online] [dostęp 10.11.2018]. Dostępny w WWW: <http://eprints.rclis.org/20429>.

Kshetri, Nir (2017). The evolution of the IoT and market in China: An interplay of institutions, demands and supply. Telecommunications Policy, vol. 41, iss. 1, pp. 49-67.

Li, Zhen; Liao, Qi (2018). Economic solutions to improve cybersecurity of governments and smart cities via vulnerability markets. Government Information Quarterly, vol. 35, iss. 1, pp. 151-160.

Luterek, Mariusz (2018). Smart City Research and Library and Information Science. Preliminary Remarks. Zagadnienia Informacji Naukowej. Studia Informacyjne, vol. 56, nr 1 (111), pp. 52-64.

Mainka, Agnes; Hartmann, Sarah; Orszullok, Lisa (2013). Public Libraries in the Knowledge Society: Core Services of Libraries in Informational World Cities. Libri, iss. 63 (4), pp. 295-319.

Muhamedyev, Ravil; Aliguliyev, Ramiz M.; Shokishalov, ZM (2018). New bibliometric indicators for productivity estimation of research fields. Annals of Library and Information Studies, vol. 65, iss. 1, pp. 62-69.

Murray, Art; Wheaton, Ken (2012). Why smart cities need smart libraries: Stories from the Alaskan frontier, KM World, vol. 21, iss. 4, pp. 1-16.

Ortner, Erich; Mevius, Marco; Wiedmann, Peter (2016). Design of Interactional Decision Support Applications for E-Participation in Smart Cities. International Journal of Electronic Government Research, vol. 12, iss. 2, pp. 18-38.

Pereira, Gabriela Viale; Parycek, Peter; Falco, Enzo (2018). Smart governance in the context of smart cities: A literature review. Information Polity: The International Journal of Government $\mathcal{E}$ Democracy in the Information, vol. 23, iss. 2, pp. 143-162.

Pînzaru, Florina; Zbuchea, Alexandra; Vițelar, Alexandra (2018). Knowledge Transfer From Business to Public Administration in Smart City Development. Proceedings of the European Conference on Knowledge Management, vol. 2, iss. 1, pp. 700-707.

Reddy, Midde Ranjit; Srinivasa, K.G.; Eswara Reddy, B. (2018). Smart Vehicular System based on the Internet of Things. Journal of Organizational \& End User Computing, vol. 30, iss. 3, pp. 45-62. 
Scholl, Hans Jochen; AlAwadhi, Suha (2016). Smart governance as key to multi-jurisdictional smart city initiatives: The case of the eCityGov Alliance. Social Science Information Sur Les Sciences Sociales, vol. 55, iss. 2, pp. 255-277.

Shu, Feng; Jing, Zhang; Yue, Gao (2016). Investment uncertainty analysis for smart grid adoption: A real options approach. Information Polity: The International Journal of Government $\mathcal{E}$ Democracy in the Information Age, vol. 21, iss. 3, pp. 237-253.

Social Science Computer Review (2018) [online] [dostęp 10 listopada 2018]. Dostępny w WWW: $<$ https://uk.sagepub.com/en-gb/eur/journal/social-science-computer-review>.

Solimine, Giovanni (2013). Nuovi appunti sulla interpretazione della biblioteca pubblica. AIB Studi, vol. 53, iss. 3, pp. 261-271.

Steenbruggen, John; Tranos, Emmanouil; Nijkamp, Peter (2015). Data from mobile phone operators: A tool for smarter cities. Telecommunications Policy, vol. 39, iss. SI, pp. 335-346.

Tan, Margaret (1998). Plugging into the wired world: Perspectives from Singapore, Information, Communication $\mathcal{E}$ Society, vol. 1, iss. 3, pp. 217-245.

The 3 Generations of Smart Cities (2018) [online] [dostęp 10.11.2018]. Dostępny w WWW: $<$ https://www.urenio.org/2015/08/25/the-3-generations-of-smart-cities>.

Tripathi, Sneha; Singh, Manendra Kumar; Tripathi, Aditya (2016). Smart Library for Smart Cities. SRELS Journal of Information Management, vol. 53, iss. 6, pp. 439-446.

Webster, C. William R.; Leleux, Charles (2018). Smart governance: Opportunities for technologically-mediated citizen co-production. Information Polity: The International Journal of Government \& Democracy in the Information Age, vol. 23, iss. 1, pp. 95-110.

Artykuł w wersji poprawionej wptyną do Redakcji 10 czerwca 2019 r.

PRZEMYSŁAW KRYSIŃSKI

Institute of Information and Book Studies

Nicolaus Copernicus University

e-mail: krys@umk.pl

\section{SMART CITY AS AN OBJECT OF INTEREST OF BOOK STUDIES AND INFORMATION STUDIES}

KEYWORDS: Smart city. Intelligent city. Book studies and information studies. Bibliometrics. Research methods.

ABSTRACT: Thesis/Objective - The article is focused on the analysis of literature on the phenomenon of smart city in the field of book studies and information studies. Only journal articles were analyzed. The author intended to confirm the presence of the topic in question in book studies and information studies literature, identify areas of interest of the researchers and discover further research trends. Research method - The critical analysis of literature was used. The research included foreign (Web of Science Core Collection, Library, Information Science and Technology Abstracts, E-LIS repository) and Polish sources (bibliographical databases of the National Library of Poland, including Polish Bibliography of Book Studies, and book studies and information studies journals). The author ana- 
lyzed the form and the content of the collected data. Conclusions - The analysis confirmed a significant interest in the phenomenon of smart city among the foreign researchers while the similar interest among Polish researchers was rather poor. The author managed to identify research areas corresponding to the publications on the potential of smart city solutions. The increasing interest in this issue in other fields of knowledge makes the author to foresee the incoming emergence of smart city concept in the field of book studies and information studies, in particular media and communication science. 